\title{
Degradation and Microstructure Changes of Tuyere Coke Behavior of a COREX-3000 Furnace
}

\author{
Haiyang WANG, ${ }^{1)}$ Jianliang ZHANG, ${ }^{1,2)}$ Guangwei WANG, ${ }^{1) *}$ Minmin SUN" ${ }^{11}$ and Qi WANG ${ }^{11}$ \\ 1) School of Metallurgical and Ecological Engineering, University of Science and Technology Beijing, Beijing, 100083 PR \\ China. \\ 2) School of Chemical Engineering, The University of Queensland, St Lucia, QLD, 4072 Australia.
}

(Received on July 9, 2018; accepted on August 21, 2018; J-STAGE Advance published date: October 4, 2018)

\begin{abstract}
The behavior of tuyere coke obtained from a COREX-3000 process was investigated in the present study for an in-depth understanding for the condition of raceway. The coke samples was obtained in a dissection process of the furnace, and coke samples at P1 (200 mm from tuyere sleeve towards the furnace center), P2 (400 mm from tuyere sleeve towards the furnace center), P3 (600 mm from tuyere sleeve towards the furnace center), P4 (800 mm from tuyere sleeve to the furnace center), P5 (1 $000 \mathrm{~mm}$ from tuyere sleeve to the furnace center) and P6 (1 $200 \mathrm{~mm}$ from tuyere sleeve to the furnace center) were sieved, and the particles size distribution and average size of different position has been calculated. Microstructure of coke samples at P2, P4 and P6 was examined using scanning electron microscopy, and carbon structure and mineral phases of coke samples at P6 were identified using X-ray diffraction (XRD) analysis. The results showed that the percentage of small coke particles $(<10 \mathrm{~mm})$ was higher at P5 and P6, and the average particle size of coke samples at P5 and P6 were $12.04 \mathrm{~mm}$ and $7.71 \mathrm{~mm}$, which is much smaller than that of other samples indicating a severe degradation of coke. The amount of pores of tuyere coke increased compared with charged coke, and more pores were found in coke sample at P6 than P2 and P4, indicating a violent reaction at this position. The graphitization degree of tuyere cokes at P6 were much higher than that of charged coke, and coke particle $(10-16 \mathrm{~mm})$ possess the highest graphitization degree, indicating the much higher temperature in the raceway zone. The main minerals in the tuyere coke were gehlenite and akermanite, and the slag was melt to be spherical particles confirming the higher temperature in raceway zone in COREX-3000 process.
\end{abstract}

KEY WORDS: COREX-3000; tuyere coke; size distribution.

\section{Introduction}

The COREX process has obvious advantages in environment protection and $\mathrm{CO}_{2}$ reduction compared with conventional blast furnace process. It is independent on coking coal to meet the requirements of environment and source, and it has been successfully operated in India, South Africa and South Korea. ${ }^{1,2)}$ Detailed information about the process and equipment of COREX can be found in the investigation by Wu et $a l .{ }^{4,5)}$

However, the pig iron cost of COREX-3000 process is much higher than that of blast furnace because of raw materials including lump coal in China. Therefore, a series of COREX-3000 processes introduced by Baosteel in 2007 was entirely moved to XinJiang province to achieve operation with low cost, and the raw materials has changed compared with the primary process. A larger amount of coke are charged into the melter gasifier to obtain better permeability of the column. However, the coke charged

* Corresponding author: E-mail: wgw676@163.com

DOI: https://doi.org/10.2355/isijinternational.ISIJINT-2018-409 into the COREX-3000 furnace is produced using low rank coke coal, which influences the properties of coke. The average Micum index ${ }^{6}$ M40 (cracking resistance index) and M10 (abrasive resistance index) of coke charged into the furnace were 86.3 and 6.8, respectively, however, the average CRI (coke reactivity index) and CSR (coke strength after reaction $)^{7)}$ were 51.34 and 35.40 , respectively, which is absolutely different from that of coke charged into conventional blast furnace.

Coke is the most important material for the column permeability in COREX-3000 furnace as in blast furnace. ${ }^{8)}$ Coke degradation occurs seriously in the furnace due to a series of complicated physical and chemical reaction and the poor CSR when it reaches tuyere zone. Tuyere drilling technique is usually used to extract samples from an operating blast furnace to provide useful information about inner phenomena in the tuyere level, ${ }^{9,10)}$ and many studies ${ }^{9-11)}$ have been done on the tuyere coke in blast furnace, however, the condition at tuyere level in COREX-3000 furnace is very different from that of blast furnace including the size of raceway and theoretical combustion temperature. ${ }^{12-14)}$ Therefore, an in-depth understanding about coke reaction 
behavior in the high temperature zone of the COREX-3000 furnace is critical to optimize the process. Coke samples in the tuyere level in the present study were extracted when the COREX-3000 furnace is shun down.

In this paper, tuyere coke samples have been examined to characterize particle size distribution, microstructure and carbon structural order at different location from tuyere sleeve. The aim of this paper is to develop an understanding of the behavior and characteristic of the tuyere coke in the COREX-3000 furnace.

\section{Samples and Methods}

\subsection{The Introduction of Blast Furnace and the Sampling Position}

Tuyere coke samples are usually extracted from an operating blast furnace using tuyere drilling technique. In the present study, the tuyere coke samples were extracted from a COREX-3000 furnace when it was shut down for overhauling. The vertical position of the sample location was at the center line of tuyere, and the horizontal position of sample location was $200 \mathrm{~mm}(\mathrm{P} 1), 400 \mathrm{~mm}$ (P2), $600 \mathrm{~mm}$ (P3), $800 \mathrm{~mm}$ (P4), $1000 \mathrm{~mm}$ (P5) and $1200 \mathrm{~mm}$ (P6) from tuyere sleeve towards the furnace center as shown in Fig. 1. The coke samples were sieved using standard sieve with size of <1.6 mm (S1), 1.6-2.5 mm (S2), 2.5-10 mm (S3), 10-16 mm (S4), 16-20 mm (S5), 20-25 mm (S6), 25-40 $\mathrm{mm}(\mathrm{S} 7),>40 \mathrm{~mm}$ (S8) in turn.

Then the mass of different coke samples was weighed, and the corresponding proportion was calculated, respectively. The average particle size was calculated according to Eq. (1)

$$
\overline{\mathrm{D}}=\sum_{\mathrm{i}=1}^{\mathrm{n}} \mathrm{D}_{\mathrm{i}} \cdot \mathrm{Y}_{\mathrm{i}}
$$

Where $\overline{\mathrm{D}}$ is average size of coke samples at some position, $\mathrm{mm}$; Di is average size of sieve size range $\mathrm{i}, \mathrm{mm}$; $\mathrm{Yi}$ is mass percentage of coke samples with sieve size range $i$.

\subsection{Microstructure Analysis}

Coke samples at P2, P4 and P6 were selected, and pieces about $10 \mathrm{~mm} \times 10 \mathrm{~mm} \times 5 \mathrm{~mm}$ were cut from the selected samples. The coke pieces were mounted in the rounded plastic container with $15 \mathrm{~mm}$ diameter filled with the epoxy resin. The specimens were ground and polished, and then they were examined with a Quanta 250 Environmental scanning electron microscope (SEM) equipped with energy dispersive X-ray spectrometer (EDS) for microstructure analysis. Coke samples at P6 were crushed to select particles(less than $74 \mu \mathrm{m}$ ) for XRD examination. The analysis was conducted using a XRD diffractometer (Rigaku Corporation) with $\mathrm{Cu} \mathrm{Ka}$ radiation. The scanning angles scope was 10 to $90 \mathrm{deg}(2 \theta)$ at a rate of $10 \mathrm{deg} / \mathrm{min}$.

\section{Results and Discussion}

\subsection{Particle Size Distribution}

Particle size distribution of tuyere coke at different position was shown in Fig. 2. The percentage of S8 (>40 mm) decreased sharply from P2 to P5, and there was no particle larger than $40 \mathrm{~mm}$ at $\mathrm{P} 6$. The percentage S7 $(25-40 \mathrm{~mm})$ increased from $\mathrm{P} 2$ to $\mathrm{P} 4$ and then decreased from $\mathrm{P} 4$ to P6. The percentage of S5 (16-20 mm) and S6 (20-25 mm) showed unclear size change tendency, and the percentage of S1 $(<1.6 \mathrm{~mm}), \mathrm{S} 2(1.6-2.5 \mathrm{~mm})$ and S3 $(2.5-10 \mathrm{~mm})$ increased accordingly, especially for the percentage of S2 and S3. The percentage of small particles increased sharply

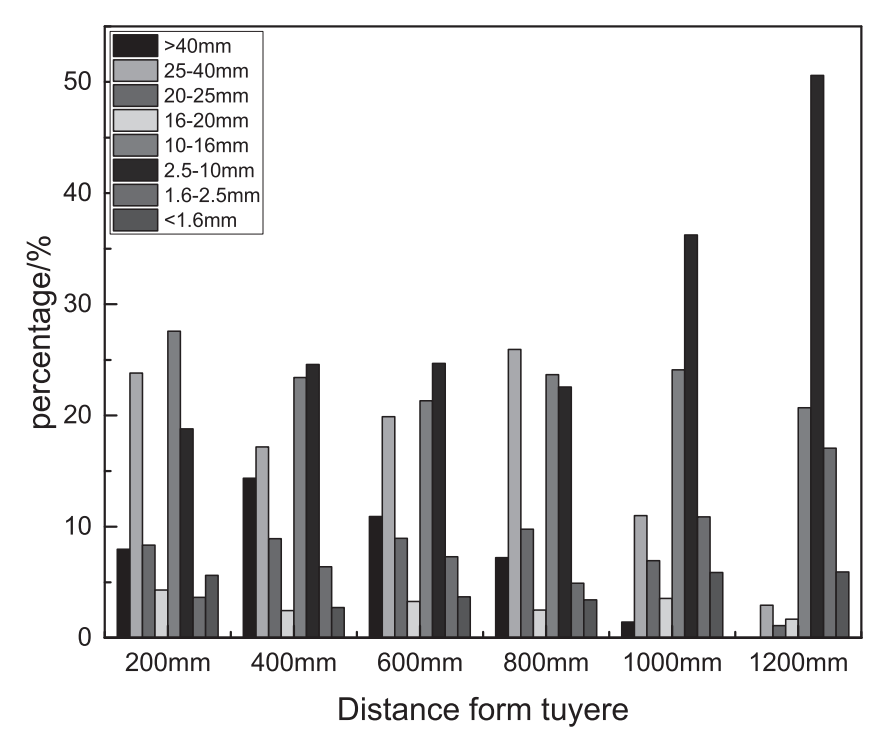

Fig. 2. Particle size distribution of tuyere coke at different position.

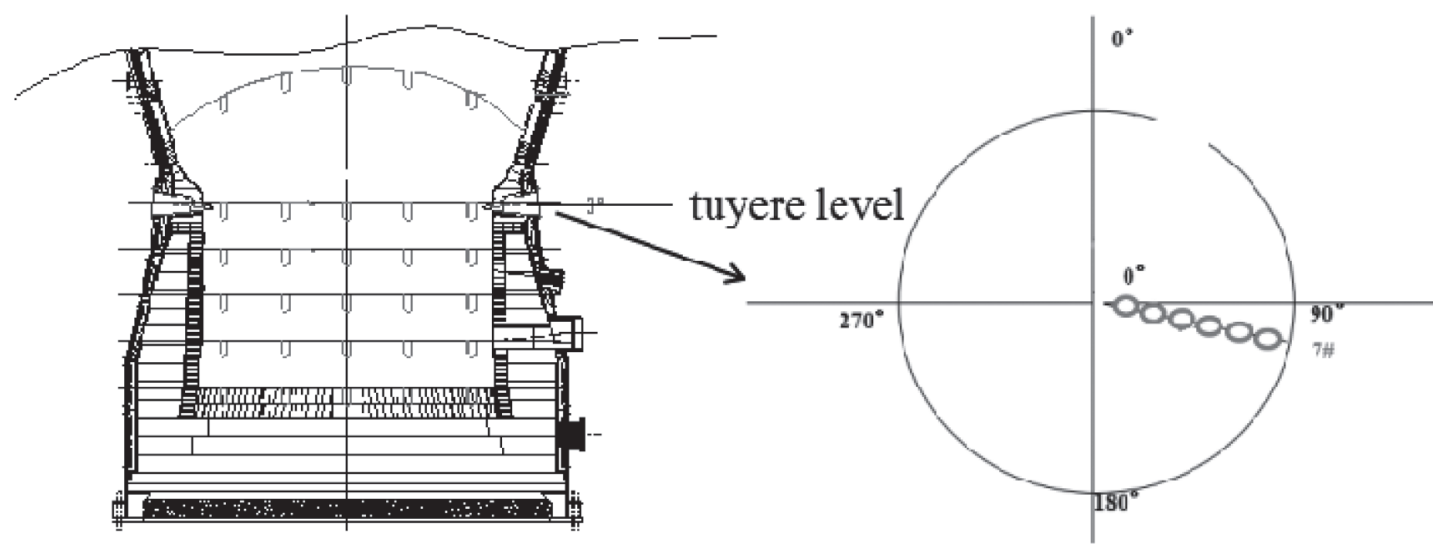

Fig. 1. The schematic of the tuyere coke sampling positions. 
from P5 to P6, indicating a serious degradation occurs at these positions.

The average particle size of tuyere coke ranged from P1 to P6 were shown in Fig. 3. It shows that the average particle size of tuyere coke at P1, P2, P3 and P4 were $18.8 \mathrm{~mm}$, $19.2 \mathrm{~mm}, 18.45 \mathrm{~mm}$ and $18.92 \mathrm{~mm}$, respectively, however, the average particle size at P5 and P6 were $12.04 \mathrm{~mm}$ and $7.71 \mathrm{~mm}$. The particle size distribution showed that the average particle size at P1, P2, P3 and P4 was almost the same, but it was much smaller at P5 and P6. It showed that more fines was product at P5 and P6 (1 $000 \mathrm{~mm}$ and $1200 \mathrm{~mm}$ from tuyere sleeve towards the furnace center), indicating serious degradation occurred at P5 and P6, and it was the beginning of the deadman zone.

The particle size distribution of the charged coke was shown in Fig. 4, and the percentage of particles with size of $40-60 \mathrm{~mm}$ is the largest, which was as high as $46.52 \%$. That of particles larger than $40 \mathrm{~mm}$ is almost $76.75 \%$, while there was no coke particles larger than $40 \mathrm{~mm}$ existing in tuyere coke samples. The average size of charged coke was 53.70

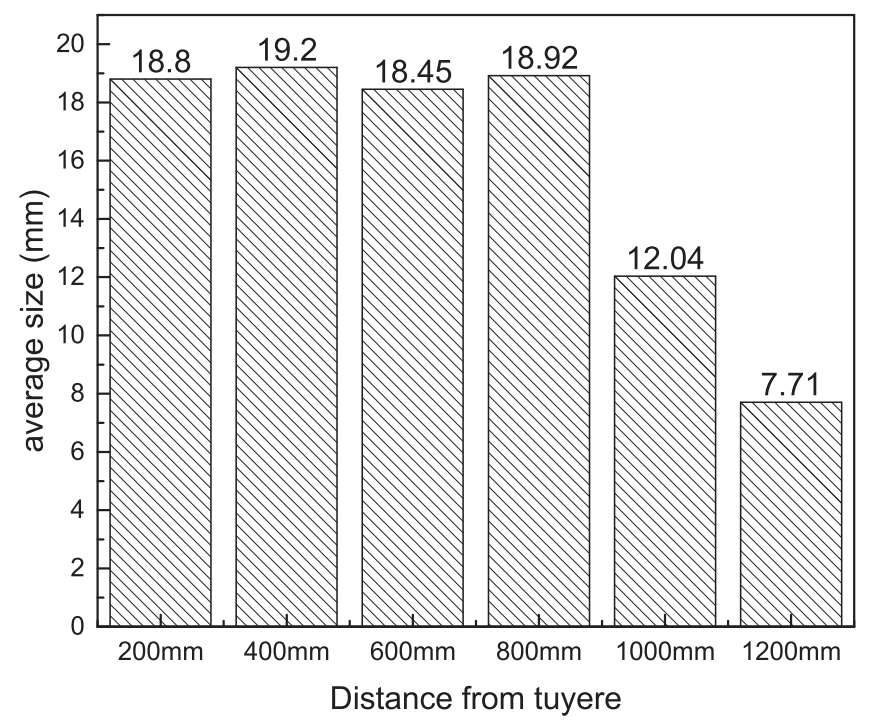

Fig. 3. The average particle size of tuyere coke at different positions.

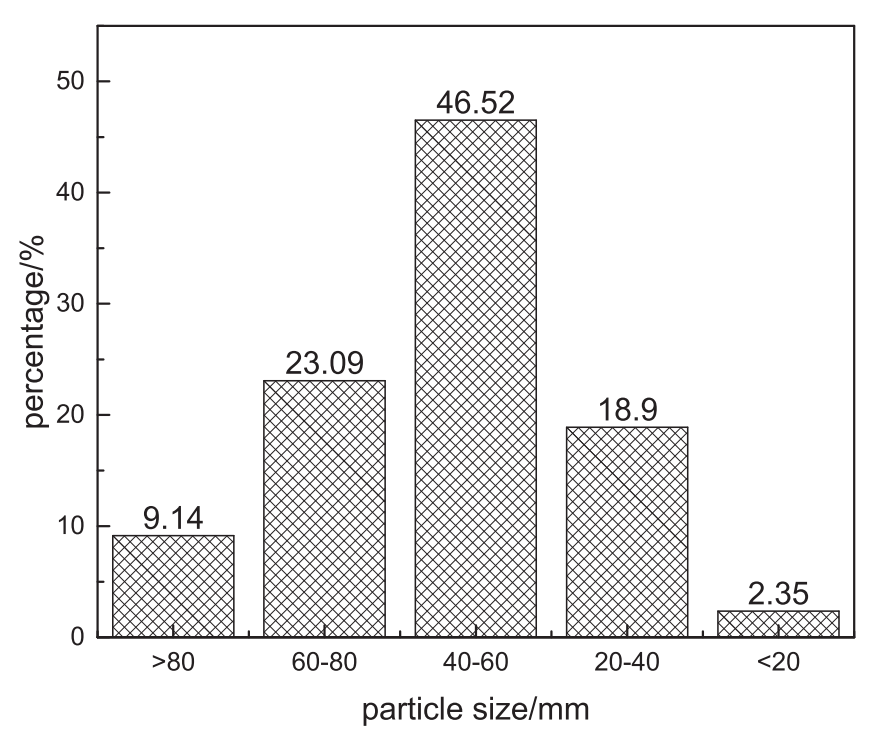

Fig. 4. Particle size distribution of charged coke. $\mathrm{mm}$, which is much larger than that of tuyere coke at any position in the present study, indicating a severe degradation process of coke in the furnace.

\subsection{Microstructure of Tuyere Coke}

Microstructure of charged coke and tuyere coke at P2, P4 and P6 was shown in Fig. 5. An amount of small open pores were observed in the charged coke, which was beneficial to diffusion of $\mathrm{CO}_{2}$. However, more pores were observed in tuyere coke samples at P2, P4 and P6 compared with the charged coke, and the size of the pores were enlarged. The pore wall of tuyere coke samples was thinner than that of charged coke due to gasification with $\mathrm{CO}_{2}$. A large amount of pores interconnected with each other were found in tuyere coke at P6 as shown in Fig. 4(d), indicating severe gasification reaction with $\mathrm{CO}_{2}$. Thinner pore wall resulted in poorer strength after reaction, and coke fine produced as well.

\subsection{XRD Analysis}

Temperature has been proved to have a great effect on the degree of graphitization of tuyere coke, and coke fines $(<74 \mu \mathrm{m})$ comes from the surface of lump coke due to high temperature. The temperature in tuyere zone of COREX-3000 furnace is much higher than that of blast furnace due to high oxygen enrichment rate, and the highest temperature in the raceway of COREX-3000 furnace is about $3500 \mathrm{~K}^{13)}$ Therefore, in-depth understanding of the effect of higher temperature on tuyere coke in this process needs to be investigated.

The XRD analysis of tuyere coke particles as well as charged coke confirmed the high degree of graphitization of tuyere coke as shown in Fig. 6. The sharp graphite (002) peak was observed in tuyere coke samples S1, S2, S3, S4 and S5, while the (002) peak of charged coke is much wider. Sharp (002) peak was not observed in tuyere coke samples S6 and S7, however, sharp (100) peak and quartz was observed in these cokes indicating larger crystal size and lower temperature compared with other tuyere coke. ${ }^{15)}$

As shown in Fig. 7, further magnification of graphite

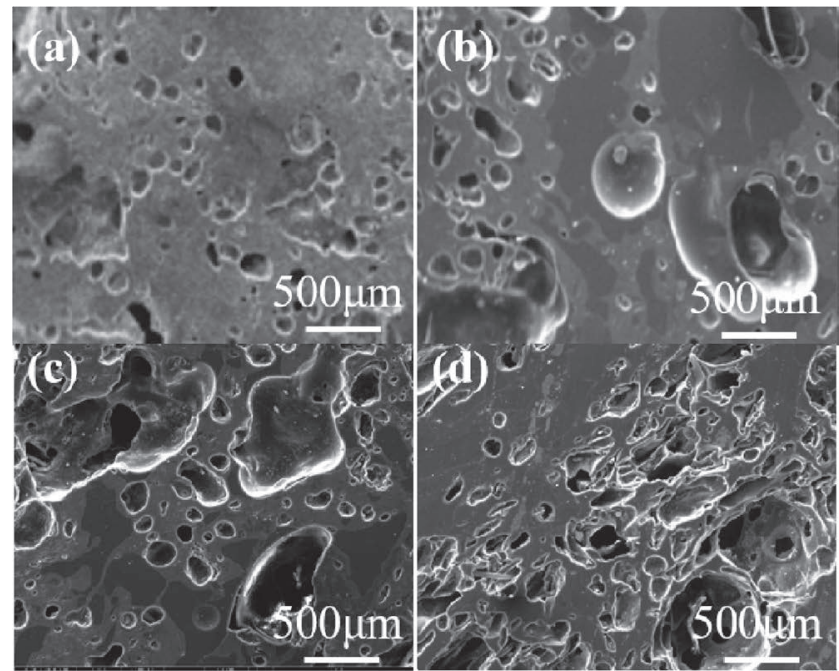

Fig. 5. Microstructure of tuyere coke at P2, P4 and P6. (a) charged coke; (b) tuyere coke at P2; (c) tuyere coke at P4; (d) tuyere coke at P6. 


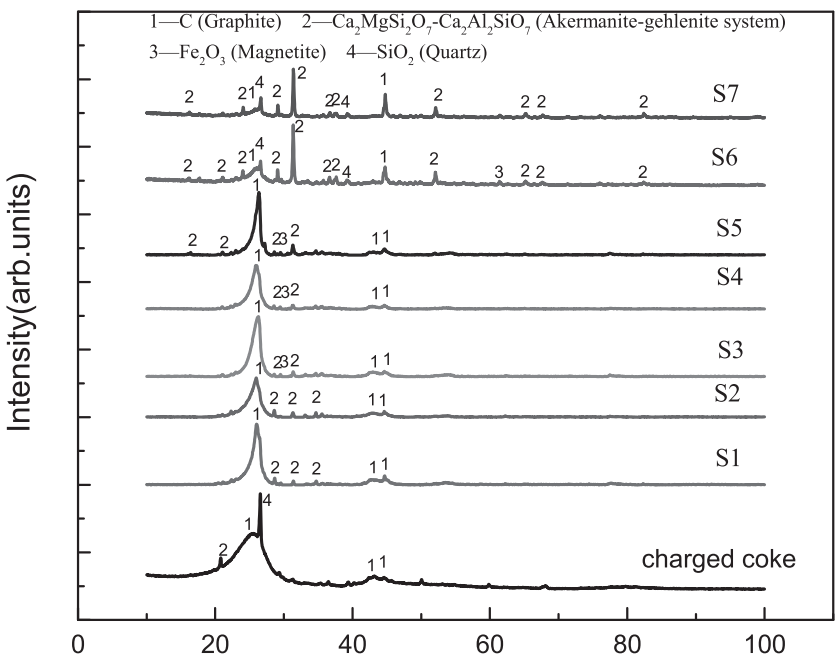

Fig. 6. XRD spectrum of tuyere coke samples with different size at P6.

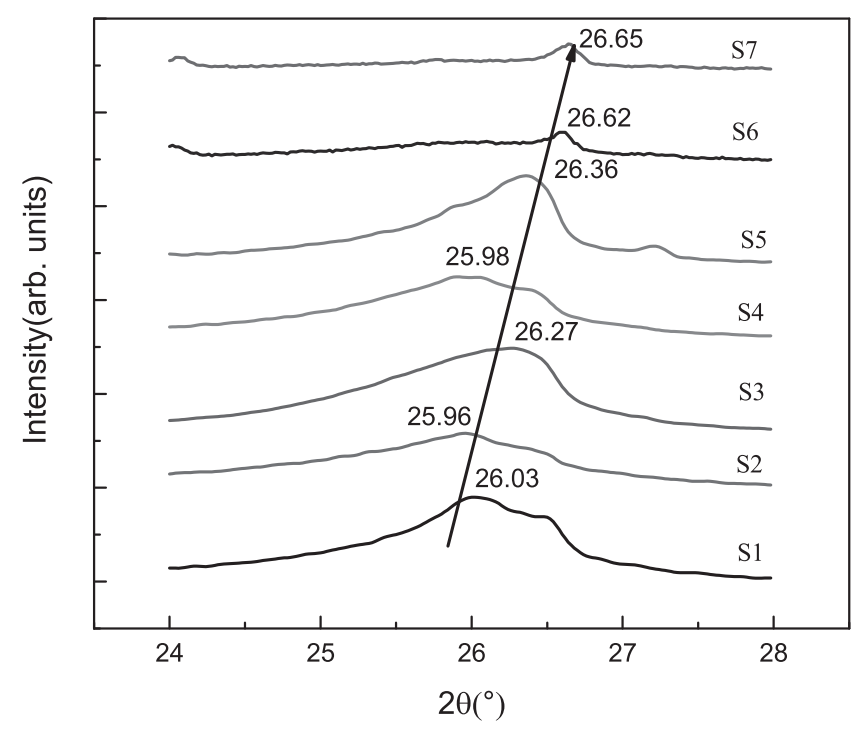

Fig. 7. Magnification of graphite (002) peak.

(002) peak area distinguished the different graphitization degree of tuyere coke samples with different size at P6. As the particle size of tuyere coke samples increased, the angles of graphite (002) peak increases except S2 and S4, indicating $d_{002}$ decreased accordingly.

The $d_{002}$ value as well as $L_{\mathrm{c}}$ and $L_{\mathrm{a}}$ estimated with Scherrer equation of tuyere coke S1 to S7 and charged coke were shown in Table 1. ${ }^{10)}$ The $d_{002}$ value of tuyere coke samples and charged coke were calculated to be $3.40,3.43,3.47$, $3.38,3.44,3.47,3.46$ and $3.52 \mathrm{~nm}$, respectively, from the Bragg's law. While the $L_{\mathrm{c}}$ values of tuyere coke samples and charged coke were estimated to be $1.79,1.77,1.40$, $2.35,1.71,1.51,1.38$ and $0.16 \mathrm{~nm}$, respectively, indicating that higher graphitization degree of tuyere coke than that of charged coke. The highest degree of graphitization of tuyere coke belongs to $\mathrm{S} 4(10-16 \mathrm{~mm})$ showing that the highest temperature it underwent.

The $L_{\mathrm{c}}$ value of charged coke was only $0.16 \mathrm{~nm}$ indicating low graphitization degree resulting in high CRI and more pores were produced after gafication reaction. While the $L_{\mathrm{c}}$ values of all tuyere coke were higher due to the effect of high temperature in raceway zone, which is usually associ-
Table 1. $d_{002}, L_{\mathrm{c}}$ and $L_{\mathrm{a}}$ of tuyere coke and charged coke.

\begin{tabular}{cccc}
\hline Sample & $d_{002} / \mathrm{nm}$ & $L_{\mathrm{c}} / \mathrm{nm}$ & $L_{\mathrm{a}} / \mathrm{nm}$ \\
\hline Charged coke & 3.52 & 0.16 & 0.53 \\
S1 & 3.40 & 1.79 & 2.47 \\
S2 & 3.43 & 1.77 & 3.06 \\
S3 & 3.47 & 1.40 & 3.02 \\
S4 & 3.38 & 2.35 & 3.99 \\
S5 & 3.44 & 1.71 & 3.87 \\
S6 & 3.47 & 1.51 & 9.20 \\
S7 & 3.46 & 1.38 & 13.69 \\
Tuyere coke from blast furnace & 3.42 & 0.25 & 4.41 \\
\hline
\end{tabular}

ate with hot metal and high theoretical combustion temperature due to high oxygen enrichment. The $d_{002}, L_{\mathrm{c}}$ and $L_{\mathrm{a}}$ value of tuyere coke from a $2500 \mathrm{~m}^{3}$ blast furnace using the same charged coke was also calculated and listed in Table 1. It showed that, the $L_{\mathrm{c}}$ value of tuyere coke from the blast furnace is only $0.25 \mathrm{~nm}$, which is much smaller than that of tuyere coke from COREX-3000 furnace indicating higher temperature in the tuyere zone of COREX-3000 furnace.

$\mathrm{Li}$ et al found that ${ }^{15)}$ the graphitization degree of coke fines $(<74 \mu \mathrm{m})$ in blast furnace hearth is higher than that of lump tuyere coke indicating that coke graphitization in the high temperature zone starts from the coke surface and leads to the formation of coke fines. Gupta ${ }^{9}$ et al. found the similar conclusion as well. However, the graphitization degree of tuyere coke S4 (10-16 mm) in the present study is the highest among all the tuyere coke samples, and the coke fines $\mathrm{S} 1(<1.6 \mathrm{~mm})$ is smaller than that of S4 $(10-16 \mathrm{~mm})$ indicating that the coke fines was not formed by surface graphitization of lump coke in the present study. The degree of graphitization of small coke particles S1, S2 and S3 is almost equal to that of lump coke S5, S6 and S7, indicating that the small coke particles comes from degradation of lump coke due to the poor CSR of charged coke and severe condition in the raceway.

The microstructure of slag in tuyere coke S4 (10-16 mm) was shown in Fig. 8 to investigate slag behavior in the tuyere coke. Spherical particles were observed in the pores of tuyere coke S4 (10-16 mm) in Fig. 8(a), and molten agglomeration was found in the pore wall (Figs.7(b) and $7(\mathrm{c})$ ). Macro pores and small pores interconnect with each other, and the pore wall has been destroyed.

The result of mapping analysis was shown in Fig. 9, and elements of $\mathrm{Al}, \mathrm{Si}$ and $\mathrm{Ca}$ were found in the spherical ash particles from tuyere coke S4 (10-16 mm) at P2, which is in accordance with the XRD analysis. The minerals in tuyere coke were determined to be akermanite $\left(\mathrm{Ca}_{2} \mathrm{MgSiO}_{7}\right)$ and gehlenite $\left(\mathrm{Ca}_{2} \mathrm{Al}_{2} \mathrm{SiO}_{7}\right)$ in XRD analysis, which are the common minerals in the continuously cooled crystalline blast furnace slag. ${ }^{16)}$

Akermanite and gehlenite are belong to melilite, which is a solid solution. The melting temperature of melilite is higher than $1673 \mathrm{~K}$, and the melting point of gehlenite is approximately $1873 \mathrm{~K}$. Final slag has been found in the pores of tuyere coke and hearth coke, ${ }^{15)}$ and it fills up the interconnected pores. However, spherical slag particle 


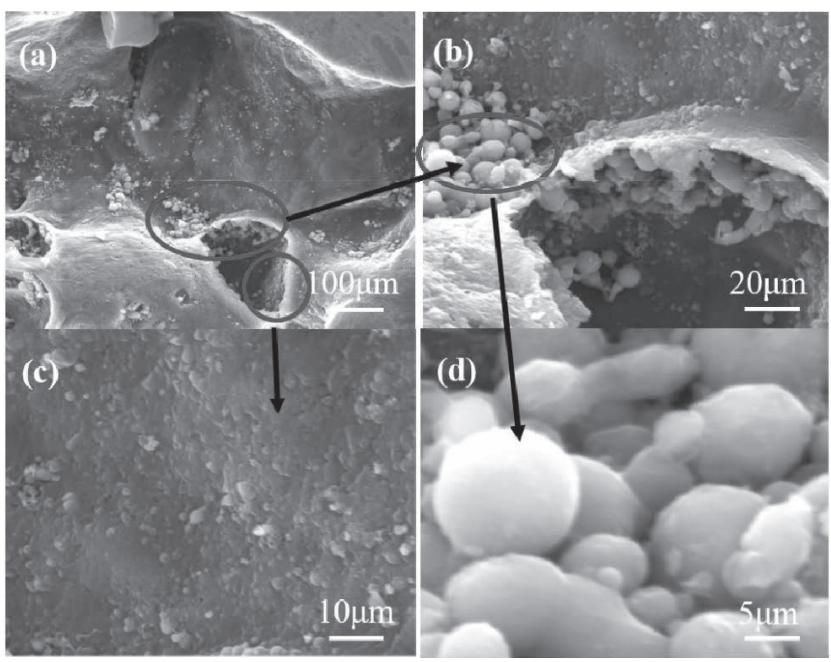

(a)mag 500×; (b) mag 2500×; (c) mag 5000×; (d) mag 10000×

Fig. 8. Microstructure of ash of tuyere coke $\mathrm{S} 4(10-16 \mathrm{~mm})$ at position P2.

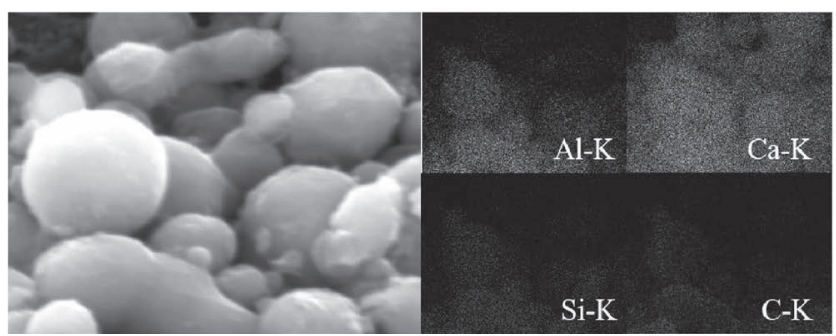

Fig. 9. Mapping analysis of the spherical ash particles.

melted by high temperature has never been found in tuyere coke in blast furnace due to lower temperature in the raceway zone of the process, therefore, the temperature in raceway of COREX-3000 process must be much higher than that of blast furnace in accordance with the XRD analysis and Du's calculating results. ${ }^{13)}$

\section{Conclusion}

Tuyere coke samples from a COREX-3000 process were examined to characterize the coke behavior, and following conclusions were made:

(1) The percentage of small coke particles $(<10 \mathrm{~mm})$ increased at P5 and P6, and the percentage of lump coke ( $>10 \mathrm{~mm}$ ) changes little from P1 to P4. The average particle size of coke samples at P1, P2, P3 and P4 were $18.80 \mathrm{~mm}$, $19.20 \mathrm{~mm}, 18.45 \mathrm{~mm}$ and $18.92 \mathrm{~mm}$, respectively, and the average particle size at P5 and P6 were $12.04 \mathrm{~mm}$ and 7.71 $\mathrm{mm}$, which is much smaller than that of the charged coke.
The sharp decrement of coke particle size indicates a severe degradation of coke in the furnace.

(2) More pores were found in tuyere coke compared with charged coke due to gasification reaction with $\mathrm{CO}_{2}$, and more pores were determined in coke sample at P6 than $\mathrm{P} 2$ and $\mathrm{P} 4$, indicating a violent reaction at this position in accordance with the result of particles size distribution.

(3) The degree of graphitization of tuyere cokes were much higher than that of the charged coke due to the effect of high temperature. Tuyere coke with different particle size showed different graphitization degree. Coke particle $(10-16 \mathrm{~mm})$ possess the highest graphitization degree, and smaller coke fines $(<10 \mathrm{~mm})$ showed lower graphitization degree as well as lump coke $(>16 \mathrm{~mm})$, indicating that the coke fines come from degradation of lump coke due to poor strength after reaction.

(4) The higher graphitization degree of tuyere coke indicated high temperature in the raceway zone of COREX-3000 process. The main minerals in the tuyere coke were gehlenite and akermanite, and the slag was melt to be spherical particles confirming the higher temperature in raceway, which is in accordance with the XRD analysis.

\section{Acknowledgements}

The present work was supported of the National Science Foundation of China (51774032) \& Yong Elite Scientists Sponsorship Program By CAST (2017QNRC001).

\section{REFERENCES}

1) A. Kadrolkar, S. K. Roy and P. K. Sen: Metall. Mater. Trans. B, 43 (2012), 173.

2) R. S. Xu, J. L. Zhang, G. W. Wang, H. B. Zuo, Z. J. Liu, K. X. Jiao, Y. X. Liu and K. J. Li: Metall. Mater. Trans. B, 47 (2016), 2535.

3) S. C. Lee, M. K. Shin, S. Joo and J. K. Yoon: ISIJ Int., 39 (1999), 319.

4) J. Sun, S. L. Wu, M. Y. Kou, W. Shen and K. P. Du: ISIJ Int., 54 (2014), 43.

5) K. P. Du, S. L. Wu, Z. K. Zhang, F. Chang and X. L. Liu: ISIJ Int., 54 (2014), 2737.

6) R. Loison, P. Foch and A. Boyer: Coke: Quality and Production, Butterworth-Heinemann, London, (1989), 170.

7) D. Vogt: 59th Ironmaking Conf. Proc., Vol. 59, Iron and Steel Society, Warrendale, PA, (2000), 47.

8) T. Hilding, S. Gupta, V. Sahajwalla, B. Björkman and J. O. Wikström: ISIJ Int., 45 (2005), 1041.

9) S. Gupta, Z. Ye, R. Kanniala, O. Kerkkonen and V. Sahajwalla: Fuel, 113 (2013), 77.

10) S. Dong, N. Paterson, S. Kazarian, D. Dugwell and R. Kandiyoti: Energy Fuel., 21 (2007), 3446.

11) J. K. Chung and N. S. Hur: ISIJ Int., 37 (1997), 119

12) J. J. Sun, Z. G. Luo and Z. S. Zou: Powder Technol., 281 (2015), 159.

13) K. P. Du, S. Q. Zhao and S. L. Wu: Nonferr. Met. Sci. Eng., 8 (2017), 8.

14) D. Andahazy, G. Löffler, F. Winter, C. Feilmayr and T. Bürgler: ISIJ Int., 45 (2005), 166.

15) K. J. Li, J. L. Zhang, Y. X. Liu, M. Barati, Z. J. Liu, J. B. Zhong, B. X. Su, M. F. Wei, G. W. Wang and T. J. Yang: Metall. Mater. Trans. $B, 47$ (2016), 811.

16) L. Gan, C. Zhang, J. Zhou and F. Shangguan: J. Non-Cryst. Solids, 358 (2012), 20. 